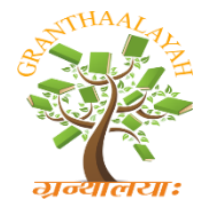

INTERNATIONAL JOURNAL OF RESEARCH GRANTHAALAYAH A knowledge Repository

Management

\title{
GOVERNMENT QUALITY; PROFESSIONALIZE THE SERVICE
}

\author{
Dra. Gabriela Valderrama Izquierdo ${ }^{1}$ \\ Mtro. Jan Fabisiak Director de International Joshep. Schumpeter ${ }^{2}$ \\ Lic. en R.I. Carla Asseneth Nava ${ }^{3}$
}

DOI: https://doi.org/10.29121/granthaalayah.v5.i4.2017.1831

\begin{abstract}
What do we call good governance and how to go forward with better practices in public administration, it is an important issue in modern societies that require appropriate legal framework in time matter, which are aimed at achieving higher and better levels of social welfare, but also take a shift towards higher levels of citizen engagement.
\end{abstract}

Keywords: Government; Quality; Practices.

Cite This Article: Dra. Gabriela Valderrama Izquierdo, Mtro. Jan Fabisiak, and Carla Asseneth Nava. (2017). "GOVERNMENT QUALITY; PROFESSIONALIZE THE SERVICE." International Journal of Research - Granthaalayah, 5(4), 369-379. https://doi.org/10.29121/granthaalayah.v5.i4.2017.1831.

\section{Introduction}

Rene Vazquez (2006) from the Weberian thesis states that "... pure bureaucratic administration, that is, bureaucratic-monocratic administration, abided by its record, is in accordance with all the experience the most rational form of domination exercised; and it is in the following instincts: accuracy, continuity, discipline, rigor and confidence; calculability (...). The development of "modern" forms of association in all types of territory (state, church, army, party, economic exploitation, association of stakeholders, unions, foundations and any others that could be cited) fully coincides with the development and growing increase of bureaucratic administration: its appearance is, for example, the seed of modern Western state." (Weber, 2002: 178 cited by VAZQUEZ, 2006)

The traditional bureaucratic organization has a vertical structure, moving towards an electronic government generates changes in standard organizational patterns of government institutions, which involves going beyond the acquisition of team and technology platforms; a punctual training for staff is required, establish a new organizational design that allows the administrative operation with features that favor a more horizontal organization. (See RIVERA, 2010, p.27). This means to set, in Weberian terms, a new rationality of public administration, with an 
increased share of responsibilities, even more so it's about restating its objective and primary function for creating an efficient interface with those who need an efficient service and those who offer it with high standards of competitiveness.

Dr. Luis Fernando Aguilar Villanueva from FLACSO Mexico (2012) points out that the new models of governance and public management have an associated particularity between the government and private companies. Today it is necessary to observe the problems of governance from their internal and exogenous factors. The trans-territorial factors impacting governance require looking beyond the municipal organization for example, it is more appropriate to handle regional governments, big city governments and inter-municipal governments as a whole to address solutions to each of their society needs.

Another approach is referring to new forms of governance, taking an example of Science and Technology in Europe, in response to the loss of confidence of its citizens in the control and regulation process. It is the European Commission that introduces changes oriented towards greater democratization in decision-making and the use of expert knowledge. Citizens and civil society can become more involved through the use of technology platforms * so they can bring their thoughts, values and goals in decision-making (Todt 2006). It's about a new public policy and a new way of appreciating risk management and this represents a distinct form of governance. *Here the concept of technology platforms, cover all relevant activities to a technoscientific subject; ethical, social acceptance, legal and regulatory aspects as well as marketing so that all relevant actors are involved.

Paradoxically, advances in science and technology and its unwanted effects, questioned in today's advanced industrial societies, become a matter of priority considered as a security issue. We are facing a "politicization of everyday life"; the government is largely outweighed by the needs of society and the concept of governance emerges as an alternative. In parallel the loss of confidence is also registered in the regulatory bodies of government.

Very important to understand that the governance processes are characterized as pluricentric, that is to say they are structured in the form of complex networks through which various actors relate to each other with a certain autonomy, but independent. (Todt 2006)

For a long time bureaucratic organization was a symbol of modern societies, sometimes even imitated by the private sector. "... The inspiration of bureaucratic administration in Weber's analysis, which appears in an idealized or stylized form, is unequivocally the efficiency, and in this sense, of course, that bureaucratic administration is a synonym for rational administration." Wanderley, \& Mitre, Maya. (2007)

The standardization of procedures is only an instrument for greater efficiency, especially when it comes to situations involving routine decisions, applicable to a large number of cases and cases. After all, as we see in Wanderley \& Mitre, Maya (2007), public administration is an auxiliary and instrumental structure, whose function is to put in practice, in the monotony of daily administrative activity, the decisions taken within the state political sphere - which are those that have to do with the purpose of state action and, as such, necessarily demand conditions for greater flexibility. All this follows a capitalist logic that begins with the privatization process in 
the early eighties which our country gave rise to the neoliberal system, international capitalism modifies the relationship between businesses, citizens and government. (GUERRERO, 2011, p. 11) An interesting example is Colombia, which ranked the third largest economy in Latin America in terms of GDP (OECD 2012) has worked on strengthening its political institutions. The 1991 Constitution has modernized its economic activity through its reforms. Colombians have improved considerably; the security situation, an increase in the mining activity and greater stability in basic products (commodities) have been observed and reflect a sustained growth activity.

Colombia has a committed participation with the Open Government Partnership (OGP) that aims for greater collaboration between government and civil society, greater use of ICT, better access to information, increased monitoring and accountability, improved transparency and fight against corruption as well as greater efficiency in providing services to the public.

\section{The OECD Conceives Governance Reform As}

"The governance reform is not an end in itself, it is a medium to achieve public policy results for its citizens and businesses efficiently and effectively." Good governance involves building a better national and regional environment in which people can live, learn and work, in which entrepreneurs can innovate and commercialize the results of their creativity, and which businesses can partake to generate wealth and employment. Good governance refers to improving confidence in the government, its institutions and the quality of its services and decisions, because it's perceived as being in the sake of public interest "OECD (2014)"

In Colombia, the 1991 Constitution substantially changes the role of the state in regulating economic activity. The state abandoned its interventionist role as sole provider of services and liberalized the economy in incrementing private sector participation, increasing therefore internal competition. Colombia's government now issues public policies and regulations that influence the private sector activity and exercise supervision and control over its implementation.

Brazil is another country occupied to modernize the structure of its public. Administration Researchers at the Department of Public Administration of the Getulio Vargas Foundation (FGV) and the School of Business Administration of Sao Paulo (EAESP) emphasize the importance it had in Brazil of the creation of the Administrative Department of Public Service (DASP) in 1938 that was key to the modernization project national-developmentalist with which began to professionalize the public sector from a public administration model, created by Getulio Vargas, based on the Weberian model of impersonality, meritocracy and professionalism.

If we consider that customer service has the principle to provide a customer or consumer a service, or as defined by experts, it is a benefit that one party can offer to each other even when it's something intangible that is, it cannot be seen as a physical product (Klöter and Amstrong 2008) is in no doubt that the government through public administration has the responsibility to meet the needs of its consumers and their expectations, as citizens we are customers to the government as a provider of services. 
As consumers of a range of services provided by the government in its three management levels; federal, state and municipal, we generate expectations of service. The quality of service provided by government agencies can be evaluated on their quality levels according to its citizens' perception. In this regard, good governance is one that values the relationship with its citizens. It is mostly the citizens, who must evaluate the quality of services. Not to omit the importance of specialized agencies dedicated to measuring satisfaction levels of citizens, one of them is Parametría which for several years have done quantitative studies on issues of general interest related to public perception.

In recent assessment of public opinion Parametría, Mexico (2014) states that: One in ten respondents in the Federal District approved the work done by the current chief of government, Miguel Angel Mancera, seemed to have reached as chief of the Federal District Government with a historic vote of 3 million 28 thousand 704 votes, that's to say $63.56 \%$ according to the data of the Federal Institute of the Federal District (IEDF, 2012) This same survey reports that: the head of the city's capital government, reached an approval from its citizens between 70 to 76\%. Although his acceptance has lowered to 6 percentage points compared to September 2013. The 2014 survey links high levels of approval with the Social Programs implemented by the government. (Parametría, 2014).

These initiatives have businesses, governments, and institutions of civil society gradually joining. "In a European context Gonzalo Escribano, Director of the Energy Programme at the Elcano Royal Institute and researcher Enrique San Martin (2014)" analyzes the role of the European Union in the management and governance of energy resources. The EU in its dual capacity as major world exporter of oil and promoter of standards for good governance is consolidating important strategies. The idea of governance in a broad sense, undergoes an evolution at high speed, in material of good governance for energy resources, the best known standard is the Extractive Industries Transparency Initiative (EITI) have set out to find the highest levels of transparency by companies and governments, here the issue of global governance can be understood as multipolar governance.

The concept of global governance has been mentioned from the second stage of the Washington Consensus, and is also a priority issue for NGOs, businesses and academics. Authors like Baland (1997) and Stiglitz (2002) put it in the center of their discussion. This initiative of the new governance in energy management is a response to corruption, lack of transparency in oil revenues, empowerment of rents by political elites, the need to develop progressive and efficient tax systems (Baland and Francois, 2000; Mehlum et.al., 2006 cited by Escribano, 2014). Given this need, campaigns such as Publish What You Pay, strengthen attitudes towards transparency.

Escribano and San Martin theses (2014) point towards better governance of energy resources, it translates to an increase in imports of oil by countries participating in the EITI initiative according to statistics from 2005 to 2011, but not to the extent that it could potentially have. There are still many countries operating from geo-political and geo-economic schemes. One aspect to bear in mind is that in the EU the importers of oil and gas are private companies and not states. However in the new model of global governance, multipolar, and multi-stakeholders imply that many governments are involved. NGOs and businesses with very different structures have to be taken into account. 
The EU adopted more than ten years ago a standard access to information generated in its three core institutions: Parliament, Council and Commission. It is in Article 255 of the constituent Treaty formerly known as the European Community, established the Regulation that defined the principles, conditions, and the limits of the right to access European Parliament, Council and Commission documents. The European Parliament's Regulation (EC) No 1046/2001 was revised in September 2006, Regulation (EC) No 1367/2006. An example of European transparency is the publication and access to information in all that concerns the protection of the environment (European Parliament and Council of the EU, 2014)

Democratic governance requires effective institutions to crystallize development objectives. The Open Government initiatives means to assume the obligation to report, generate access, facilitate data reuse and open channels of participation through new technologies of information and communication in an integrated manner. In practical terms it is regarding 'open data' which involves the creation of "portal transparency" so that governments went from being service providers to becoming platforms managers, allowing users of information to generate new economic activities and add value. There is an initiative which brings together leaders from 50 countries in the five continents under the slogan, Government 2.0. With the design and implementation of collaborative platforms and intensive use of Web 2.0 and social networks, communication and participation actors are facilitated with the experience of citizens in its design of public policies and of public services provisions.

The Doing Business Project World Bank generates knowledge oriented towards the improvement of the private sector activity. In a global economy characterized by constant changes and transformations a set of standards contribute to an equality in conditions, aimed at achieving greater transparency and fair competition. It is the private sector that has marked the international guideline to good practices in business regulation. "Some important data generated by the Doing Business Report (2014) indicate that in 2012/2013, 114 economies introduced 238 regulatory reforms that facilitated business that is to say $18 \%$ more reforms than the year before. This means that if countries around the world continue these reforms they would save 45.4 million days each year in red tape. "Some of the more advanced economies according to the Doing Report (2014) are Ukraine, Rwanda, Russian Federation, the Philippines and Kosovo. Nine of the 20 economies with major reforms since 2009 belong to sub-Saharan Africa and all its economic indicators have improved. It seems remarkable to note what aspects Doing Business analyzes and monitors changes in regulations applicable to small and medium companies. It focuses on 10 areas of its cycle such as: inauguration of businesses, dealing with construction permits, obtaining electricity, registering property, obtaining credit, investment protection, paying taxes, trading across borders, enforcing contracts and resolving insolvency. (World Bank 2014). According to PNUD of the UN, the middle classes in developing countries are growing strongly, this should result in higher levels of education. A broad middle class require quality services, cooperative governments from a shared management with other social actors.

Several authors determine the most important to know the feelings of ordinary citizens in the area of services, (Parasuranam, Zeithlam and Berry, 1985, cited in UVEG, 2014) and can see that is the issues of accessibility issues, communication, homogeneity and determining compliance as to assess the quality of service aspects. The first concerns the service is available to consumers and that they have a timely and efficient response. The second refers to the service is described 
accurately and easily, so it is available to the client. It is expected that any official has detailed knowledge of the process or service offering that is that there is consistency in the information provided. And finally that full compliance is given within reasonable parameters expected.

No less important is that staff have some skills and capacities of the area it represents. It is expected to perform their activities with courtesy and kindness, credibility (that citizens really feel cared), respect for rules and deadlines established by the institution, responsiveness. Customer satisfaction goes through each of the officials who have contact since reaching a government institution; the police, the secretariat, the doctor, the official shop, etc). It is expected that the official has knowledge of the process in its entirety, in a nutshell that is professional.

It is recommended that institutional policies are developed considering the information that can provide those officials who have direct contact with the customer, who know their needs and expectations and not only because of the administrative or management personnel. The client, in this case the citizen expects public institution complies with what has been established as Mission. Customer satisfaction depends on working together from start to finish.

To determine consumer needs of a service should be determined at first to whom the service is offered, in the case of government public agencies the service is offered to citizens so it is essential to determine the needs of a population, know the characteristics of a service is something intangible to the extent that it is not a specific product, rather it is an experience that is perceived. The service is variable because you cannot standardize strictly; It depends on who offers the place and time yet to standardize protocols as far as possible service processes and of course to have trained personnel are sought. It is inseparable means that at the moment is produced and consumed. And it is permanent in the case of services provided by the state, if the client does not receive the service at the right time is lost forever; it is important to address the fluctuation characteristics of the service through a planning and scheduling services the population served.

A service is something intangible to the extent that it is not a specific product, rather it is an experience that is perceived. The service is variable because you cannot standardize strictly; It depends on who offers the place and time yet to standardize protocols as far as possible service processes and of course to have trained personnel are sought. It is inseparable means that at the moment is produced and consumed. And it is permanent in the case of services provided by the state, if the client does not receive the service at the right time is lost forever; it is important to address the fluctuation characteristics of the service through a planning and scheduling services.

\section{How Customer Relationships are Established}

Think of marketing government forces change the classic paradigm refers to a transaction-based to a relationship-based trade exchange. My clients are partners and the relationship I have with them as an institution long term is therefore the need to maintain relationships through quality and innovation processes is essential.

When it comes to a public service paradigm shifts towards a strategic vision to retain or keep the client with a strategy based on relationships that involve changing the mindset, organizational 
culture and reward system itself. This is to benefit the organization, to care for the prestige of the institution for it will have to attract, retain, and strengthen customer relationships.

Satisfied customers benefit the long-term institution. Build confidence, feelings of security by the provider, reduces the risk and anxiety, and generates loyalties or clientele. In a context each time more competitive the government should raise its standards of competitiveness given that service users can migrate to the private sector when they find best satisfactions. An institution that keeps satisfied customers, lower marketing costs, generate free publicity through word of mouth communication. You can offer spaces stability to their employees, you can invest more in quality training. The quality of service depends on customer satisfaction, excellence only establishes long-term relationships. Of crucial importance is market segmentation, it depends which can have a clearly defined knowledge of my clients and can offer a service in response to the characteristics and specifications of the population served. Overcrowding is an issue that must be addressed, even with growing populations and this attention should correspond according to social profiles.

can be segmented considering demographic characteristics such as age, sex, income level, cultural level. Geographic characteristics; country, autonomous province, geographical area and here we can add that cultural aspects of communities cannot be omitted in the service specification. Psychographic segmentation attends social class, lifestyle and personality. There are services such as catering tourism sectors responding to sexual diversity with excellent results; as is the case Pink Money. You can segment is also considering whether the service is known or not known.

All segments must be amenable to measurements, with the observation that only a developed society with a strengthened civics with high rates of participation can ensure accountability. These should be accessible, appropriate, attractive, stable size. We should also consider the size and growth of the segment, if the segments are attractive because of its structure, objectives and resources available to the Company or institution account in the case-governmental organization.

\section{How to segment?}

It will first determine the homogeneity or heterogeneity of clients, determine consumer profiles. Evaluate whether the segment is attractive according to their size, growth and stability. Establish service goals. Evaluate the skills and service offered. The service evaluation process is necessary to measure the degree of customer satisfaction. Usually done through a survey annually, although some government institutions make periodic evaluations of the service they offer such is the case of SAT

In Mexico there is the Strategic Model for innovation and quality in government. This model is centered provide good service to Mexican society (voters, taxpayers, users, citizens) with participation of the whole society define each agency and entity projects and programs to help form a good government. The model has two major challenges as being innovative and maintain quality which implies a change of attitude in public officials and government structure good governance is one that meets the demands of society (UVEG, 2014). " 
This new model for the Mexican Administration intends to change from internal organization to how to face the challenges with competence and flexibility. It has as its mission, the government can satisfy the citizens and thereby achieve regain credibility. It is also expected to reduce the enormous burden of bureaucracy, through efficient processes. Concepts such as quality, innovation, strategic planning, process reengineering borrowed from other disciplines make up what is called corporate governance.

It is proposed to maintain a global and inclusive vision, based on collaborative work and team attached to specific projects with international quality standards for maximum utilization of resources.

\section{The Model Includes Aspects Such As}

Credibility focused on regaining the confidence of citizens. Total Quality intending to meet expectations. Generate an attitude of pride on the part of public servants. Innovation Competitiveness (UVEG, 2014)

The transformations in all areas of service of current governments are priority, however the procurement and contracting process is especially susceptible to improvements. Some agencies have already achieved modernization in this area. Many times purchases are made directly, but in the case of services is used to outsourcings. This last resort from a business point of view has its advantages in the service, not from an employment standpoint because usually these service companies pay very low wages and are completely out of benefits traditionally had given the working class, in other words they contribute to job insecurity

In Mexico, in April 2003 with 374 votes in the House of Representatives and 93 votes in the Senate, it was approved unanimously reform that prompted the Professional Career Service, which crystallized from a law establishing a service seven subsystems; the planning, income, career development, training and certification of skills, performance evaluation, separation and monitoring and evaluation of the service. March 31 for the Regulation of the Law on Professional Career Service that regulates how government through public squares and open competition based on merit and equal opportunities concerned was issued. Jose Luis Mendez (2009) in his interesting article Professional Career Service in Mexico and Godot arrived ... To stay?, he notes that even with advances in the field, hiring occur very slowly, problems that have arisen define profiles and personnel structures among other inconveniences, which has led many officials of the Ministries of Foreign Affairs, Navy, Public Security and other decentralized bodies have left the scheme of professional service career, leaving 43,000 of the 62 thousand who were already working under this scheme. We can see that much remains to be done, it will not be easy task, perhaps to be seen spending a whole generation product of a new civic and citizenship education commitments to acquire high society.

Fewer States manage and administer as they did in the past. "To understand the evolution of the public sector in the case of the United States, you can review the work of Dr. Joseph Stiglitz, Economics of Public Sector (1995)". 
Now, we have more states that contract, regulate, evaluate. Governance, a concept that takes increasing impact on our societies as a new way of managing public policies, to a primordial need to draw local, regional, state, federal, international public action, with a view to achieving the common good . (Zurbinggen, 2011) Then the sense of governance emerges as a different style of hierarchical control mode that was in effect in the past government. Today there is greater cooperation between government and public administrations and governmental actors, the media and advances in communications have played an important role in this approach, in this interdependence.

In the United States Osborne and Ted Gaebler David authors of Reinventing Government: How the Entrepreneurial Spirits Is Transforming the Public Sector poses a structured reform for the government sector, proposed in the nineties, maximum economy government accounts. David Osborne was once the principal adviser to Vice President Al Gore and its programs have been very successful.

Source: SANTANA and Negron (1996) Journal of CLAD Reforma y Democracia No. 6 Caracas. Prepared.

With this strategy it suggested that the US government was characterized by its productivity and efficiency.

\section{Conclusion}

The term governance arises from the idea of "good governance" and describes the changes that occur in the political system at the local or international levels in the private, public and civil systems. This implies that legitimacy is achieved not only be an effective and efficient government, is required to be a government that is accountable, that conforms to transparency, which contribute to some extent to generate greater citizen participation.

Current governments play in strongly service growth economies, which require greater transparency, greater administrative flexibility. They are increasingly subject to evaluation processes. Another feature is that match Models of Decentralized Management, although the government of Mexico in recent months seems to return to a model strongly centralized at least so let see some reforms: the creation of INE and the budget for payroll industry educational. Also worth mentioning that economies are centered on the service sector are increasingly making contracts through outsourcings trampling basic labor rights of workers. Although, these businesses also contribute to good business performance. In emerging countries outsourcing could be linked to a first job under a training scheme tighter, more competitive and better paid.

Current governments are governments generally have an intensive use of technology. In countries like Mexico still far these management models a reality; institutions as responsible for seeking justice and Medical Services as the IMSS (states) often do not provide professional care remain highly bureaucratized institutions. It is the Tax Attention, SAT government area that presents better performance. Has its automated services, a very friendly page, the steps are clear and simple. In addition the system works under appointments, schedules respected and somehow also the customer / citizen discipline to meet the standards of the institution. We can say that in 
general people who serve the public are extremely friendly and are trained. Other institutions have part of their automated processes but have not traveled to virtual environments or intensive use of new technologies.

Excessive bureaucracy is not unique to our country or of developing countries; societies such as Spanish and others have huge bureaucracies and very slow processes in their dealings such as the Ministry of Interior and the attention given to migrants. In Mexico the National Institute of Migration has improved its processes, but much remains do to solve the huge backlog in processing serving this office in each of the States, despite the digitization process initiated in 2006. Very successful initiatives are observed internationally regarding the Environment and Market hydrocarbons, greater transparency leads to a better democracy. The growth of the middle classes in emerging countries and the resulting increases in welfare levels require better educated societies change governance schemes to achieve better levels of development.

\section{References}

[1] AGUILAR Villanueva, Luis [FLACSO-México] (2012, Julio, 17) Las políticas públicas de la nueva gobernanza democrática, Ver: https://www.youtube.com/watch?v=bDEXkbyTRWI

[2] BANCO MUNDIAL, (2014) Doring Business 2014 Entendiendo las regulaciones para las pequeñas y medianas empresas. Comparando las regulaciones empresariales para empresas de 189 economías, Versión en línea:

http://espanol.doingbusiness.org/ /media/GIAWB/Doing\%20Business/Documents/AnnualReport s/Foreign/DB14-minibook-spanish.pdf

[3] Comunicación de la Comisión, de 25 de julio de 2001, «La gobernanza europea - Un Libro Blanco» [COM (2001) 428 final - Diario Oficial C 287 de 12.10.2001]. http://europa.eu/legislation_summaries/institutional_affairs/decisionmaking_process/110109_es.ht $\mathrm{m}$

[4] COUE (2014) Reglamento (UE) No 517/2014 del Parlamento Europeo y del Consejo, 16 de abril de 2014, Sobre los gases fluorados de efecto invernadero y por el que se deroga el reglamento (UE) No 842/2006 Ver:

https://www.fluorocarbons.org/uploads/The_Review_of_the_Regulation/FGas_Regulation_517/F _Gas_517_2014_ES.pdf

[5] ESCRIBANO Francés Gonzalo y Enrique San Martín (2014) La Unión Europea y el buen Gobierno de los recursos energéticos, en Revista CIDOB d'Afers Internacionals n. 108 p. 95-118 Versión electrónica: http://www.google.com.mx/url? $\mathrm{sa}=\mathrm{t} \& \mathrm{rct}=\mathrm{j} \& \mathrm{q}=\&$ esrc=s\&source $=$ web $\& \mathrm{~cd}=10 \& \mathrm{ved}=0 \mathrm{CGYQFjAJ} \& u r l=\mathrm{http} \% 3 \mathrm{~A} \% 2 \mathrm{~F} \% 2 \mathrm{Fwww} . \mathrm{c}$ idob.org\%2Fen\%2Fcontent\%2Fdownload\%2F43582\%2F636150\%2Ffile\%2F95118ESCRIBAN O_GONZALO_SAN\%2BMARTIN_ENRIQUE.pdf\&ei=1m0NVYr7KePLsATJ_ICQAg\&usg=A FQjCNFMtgot6Va1p183lurtpIutglnMcQ

[6] FERNÁNDEZ, Luis F. (2011). Burocracia e política no Brasil: Desafios para a ordem democrática no século XXI. Gestión y política pública, 20(2), 523-532. Recuperado en 19 de junio de 2014, de http://www.scielo.org.mx/scielo.php? script=sci_arttext\&pid=S1405$10792011000200009 \& \operatorname{lng}=\mathrm{es} \& \operatorname{tlng}=\mathrm{es}$

[7] LEFORT, Fernando. (2003). GOBIERNO CORPORATIVO: ¿QUE ES? Y ¿COMO ANDAMOS POR CASA? Cuadernos de economía, 40(120), 207-237. Recuperado en 19 de junio de 2014, de http://www.scielo.cl/scielo.php?script=sci_arttext\&pid=S071768212003012000002\&lng=es\&tln $\mathrm{g}=$ es. 10.4067/S0717-68212003012000002 
[8] MÉNDEZ José Luis (2009) El servicio profesional de Carrera en México y Godot llegó, pero... ¿para quedarse?, en Pardo María del Carmen y Ernesto Velasco Sánchez (Coord.) (2009) La Gerencia Pública en América del Norte. Tendencias actuales de la Reforma Administrativa en Canadá, Estados Unidos y México, Colegio de México (Centro de Estudios Internacionales) e Instituto de Administración Pública de Nuevo León, México pp. 195-210

[9] OCDE (2014) Adam Knelman Ostry (Coord.) Colombia la implementación del buen gobierno. Estudios de la OCDE sobre Gobernanza Pública. Colombia la implementación del buen gobierno. Versión electrónica:

https://books.google.com.mx/books?id=Fq0SBAAAQBAJ\&pg=PA251\&lpg=PA251\&dq=Eurost ats+sobre+buen+gobierno+o+gobernanza+en+Europa\&source=bl\&ots=2Nze8Q1 AnA\&sig=hAC uiKKYaEttlsuvt85ym9ad0Y\&hl=en\&sa=X\&ei=XFINVdepB4rasASsv4DQDA\&ved=0CDQQ6A EwAg\#v=onepage \&q=Eurostats\%20sobre $\% 20$ buen $\% 20$ gobierno $\% 20 \mathrm{o} \% 20$ gobernanza $\% 20 \mathrm{en} \% 2$ 0 Europa \&f=false

[10] PARDO María del Carmen y Ernesto Velasco Sánchez (Coord.) (2009) La Gerencia Pública en América del Norte. Tendencias actuales de la Reforma Administrativa en Canadá, Estados Unidos y México, Colegio de México (Centro de Estudios Internacionales) e Instituto de Administración Pública de Nuevo León, México, 583p.

[11] ONU (2013) Informe sobre el Desarrollo Humano 2013-El ascenso del Sur: Progreso Humano en un Mundo Diverso. Programa de las Naciones Unidas para el Desarrollo, Nueva York. Versiòn electrónica en:

http://www.undp.org/content/dam/undp/library/corporate/HDR/2013GlobalHDR/Spanish/HDR20 13\%20Report\%20Spanish.pdf

[12] PIMIENTA, Carlos César. (2002). Gestión de compras y contrataciones gubernamentales. RAE eletrônica, 1(1), 1-13. Retrieved March 15, 2014, from

http://www.scielo.br/scielo.php?script=sci_arttext\&pid=S167656482002000100013\&lng=en\&tln $\mathrm{g}=$ es. $10.1590 / \mathrm{S} 1676-56482002000100013$

[13] Universidad Virtual del Estado de Guanajuato (UVEG, 2014) EICS6002_M1AA1L1_Conceptos. Irapuato, Guanajuato.

[14] VÁZQUEZ García, René. (2006). Weber y su concepción de la democracia posible. Andamios, 3(5), 213-236. Recuperado en 15 de marzo de 2014, de

http://www.scielo.org.mx/scielo.php?script=sci_arttext\&pid=S187000632006000200011\&lng=es \&tlng=es.

[15] REIS, Fábio Wanderley, \& Mitre, Maya. (2007). Weber and politics. Teoria \& Sociedade, 3(se) Retrieved March 15, 2014, from

http://socialsciences.scielo.org/scielo.php?script=sci_arttext\&pid=S1518

[16] RIBERA Ortiz Any y Ángel Emiro Páez Moreno, Innovación, Burocracia y Gobierno Electrónico la Administración Pública en HOLOGRAMATICA, Revista de la Universidad del Zulia,Facultad de Ciencias Sociales UNLZ, Año VII, Número 12, V2 (2010), pp. 25-42 ISSN 1668-5024 en: http://www.cienciared.com.ar/ra/usr/3/895/hologramatica_n12vol2pp25_42.pdf

[17] STIGLITZ Joseph (1995) La economía del Sector público, Trads. María Esther Rabasa y Luis Toharia, Universidad de Alcalá, Revisión y comentarios al Capítulo 2, Antoni Bosch, Universitat Pompeu Fabra, segunda edición, Antoni Bosch Edito Barcelona.

[18] TODT, Oliver. La gobernanza tecnocientífica en la Unión Europea. Rev. iberoam. cienc. tecnol. soc. [online]. 2006, vol.3, n.7 [citado 2014-08-02], pp. 21-42. Disponible en: . ISSN 1850-0013.

[19] Zurbriggen, Cristina. (2011). Gobernanza: una mirada desde América Latina. Perfiles latinoamericanos, 19(38), 39-64. Recuperado en 19 de junio de 2014, de http://www.scielo.org.mx/scielo.php?script=sci_arttext\&pid=S018876532011000200002\&lng=es \&tlng=es

*Corresponding author.

E-mail address: gvizquierdo@yahoo.com.mx 